\title{
A REVIEW OF IN-CANOPY AND NEAR-CANOPY SPRINKLER IRRIGATION CONCEPTS
}

\author{
F. R. Lamm, J. P. Bordovsky, T. A. Howell, Sr.
}

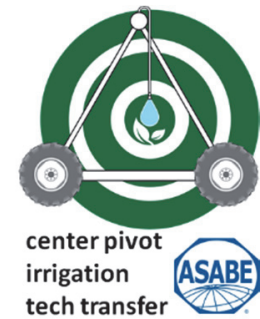

Collection

Review

ABSTRACT. The use of in-canopy and near-canopy sprinkler application with mechanical-move systems is prevalent in the U.S. Great Plains. These systems can reduce evaporative losses by nearly $15 \%$, but they introduce a much greater potential for irrigation non-uniformity and other water losses. This article is a review of these application technologies for mechanical-move sprinkler irrigation systems that have been widely adopted in the region, where irrigation capacities are typically less than those required to meet "fully irrigated" crop water demand and there is limited seasonal precipitation. Close attention to the design, installation, management, and operating guidelines for these systems can prevent many of the nonuniformity and water loss issues that reduce system performance and crop water productivity.

Keywords. Center pivot, In-canopy sprinkler application, LEPA, LESA, LPIC, MESA, PARM, Sprinkler irrigation.

I $\mathrm{n}$ the U.S. Great Plains, center-pivot (CP) sprinkler irrigation is the predominant irrigation method. There are far fewer linear lateral-move (LL) sprinkler irrigation systems, and together with $\mathrm{CP}$ systems they are jointly termed mechanical-move (MM) sprinkler irrigation systems. Windy and semi-arid conditions in the region during the growing season affect MM irrigation uniformity and evaporative losses. As a result, many producers have adopted MM sprinkler systems and methods that apply water at a lower height within or near the crop canopy height, thus avoiding some of the application nonuniformity caused by wind and droplet evaporative losses. However, these sprinkler systems are often adopted without appropriate understanding of the requirements for proper water management, and thus other problems occur, such as runoff and poor soil water redistribution (Evans et al., 1998; Foley et al., 2006; Lamm and Porter 2017). This article discusses in-canopy and near-canopy MM sprinkler irrigation from a conceptual standpoint with supporting data from research studies conducted in the U.S. Great Plains region and beyond.

C $(9)$ The authors have paid for open access for this article. This work is licensed under a Creative Commons AttributionNonCommercial-NoDerivatives 4.0 International License https://creative commons.org/licenses/by-nc-nd/4.0/

Submitted for review in November 2018 as manuscript number NRES 13229; approved for publication as an Invited Review and as part of the Center-Pivot Irrigation Tech Transfer Collection by the Natural Resources \& Environmental Systems Community of ASABE in February 2019.

Contribution No. 19-220-J from the Kansas Agricultural Experiment Station.

The authors are Freddie R. Lamm, Professor and Research Irrigation Engineer, Northwest Research-Extension Center, Kansas State University, Colby, Kansas; James P. Bordovsky, Senior Research Scientist and Agricultural Engineer, Texas A\&M AgriLife Research, Plainview, Texas; Terry A. Howell, Sr., Laboratory Director and Research Agricultural Engineer (Retired), USDA Agricultural Research Service, Lago Vista, Texas. Corresponding author: Freddie R. Lamm, P.O. Box 505, Colby, KS 67701; phone: 785-462-6281; e-mail: flamm@ksu.edu.

\section{GUIDELINES, DEFINITIONS, AND DESCRIPTIONS}

Traditionally, MM sprinkler irrigation systems have been designed to apply water uniformly to the soil at a rate less than the soil intake rate to prevent runoff from occurring (Heermann and Kohl, 1983; Scherer et al., 1999). These design guidelines need to be either followed or intentionally circumvented with appropriate design criteria and other cultural practices for managing a MM system that applies water within the canopy or near the canopy height where the sprinkler application pattern is intercepted by the plant canopy. Peak application rates can easily be 5 to 30 times greater for in-canopy sprinklers than for abovecanopy sprinklers (fig. 1). Peak application rate is a direct function of the system length, the irrigation capacity (flow rate per unit ground area irrigated), and the application technology's wetted diameter and is independent of the application depth

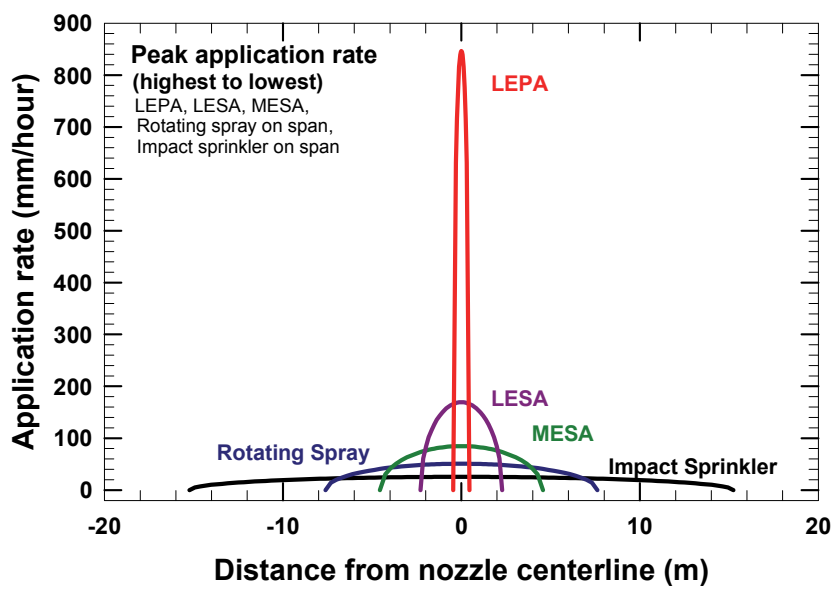

Figure 1. Typical application rates for various sprinkler systems to apply an equivalent irrigation depth. Curves from highest to lowest are LEPA, LESA, MESA, rotating spray, and impact sprinkler. 
(Martin et al., 2007).

A number of sprinkler systems have been developed that apply water in the crop canopy or near the canopy height. They should be and are classified as systems because they involve sprinkler irrigation hardware as well as installation and management guidelines (table 1 and fig. 2). Low-energy precision application (LEPA) was probably the earliest in-canopy application system for MM irrigation, although there had been earlier attempts with traveling drip irrigation systems (Rawlins, 1974). A prototype LEPA system was developed as early as 1976 by Bill Lyle at Texas A\&M University. Jim Bordovsky joined the development effort in 1978 (McAlavy and Dillard, 2003), and the first scientific publication of their work was in 1981 (Lyle and Bordovsky, 1981). Although LEPA was originally used in every furrow, subsequent research (Lyle and Bordovsky, 1983; Bordovsky et al., 1984, 1992; Bordovsky and Lyle, 1996) demonstrated the superiority of alternate-furrow LEPA. The reasons for this superiority are not always evident, but they may be due to the deeper irrigation penetration (twice the volume of water per unit wetted area compared with every-furrow LEPA), possible improved crop rooting and deeper nutrient uptake, and less surface water evaporation ( $\sim 30 \%$ to $40 \%$ of the soil is wetted). Seven guiding principles (table 2) necessary for successful LEPA were given by Lyle (1992).

There are overlaps in definitions among in-canopy and near-canopy sprinkler irrigation systems, as well as differences in their focus (table 1 and fig. 1). LEPA and LPIC were both initially developed when there was an intense focus on irrigation energy costs, so they both emphasize aspects of energy within their name. LPIC was partially developed as an alternative to LEPA for tighter soils and steeper topography, where preventing runoff was difficult with LEPA. Irrigators using LPIC systems often have difficulties strictly adhering to LEPA principles 2, 3, 5, and 6 (table 2), but many irrigators still believe that they are obtaining most of the benefits of LEPA. In fact, many LPIC systems are inaccurately called LEPA systems in the U.S. Great Plains. In a worthwhile attempt to clarify and prevent misuse of incanopy and near-canopy irrigation technologies, the USDA-

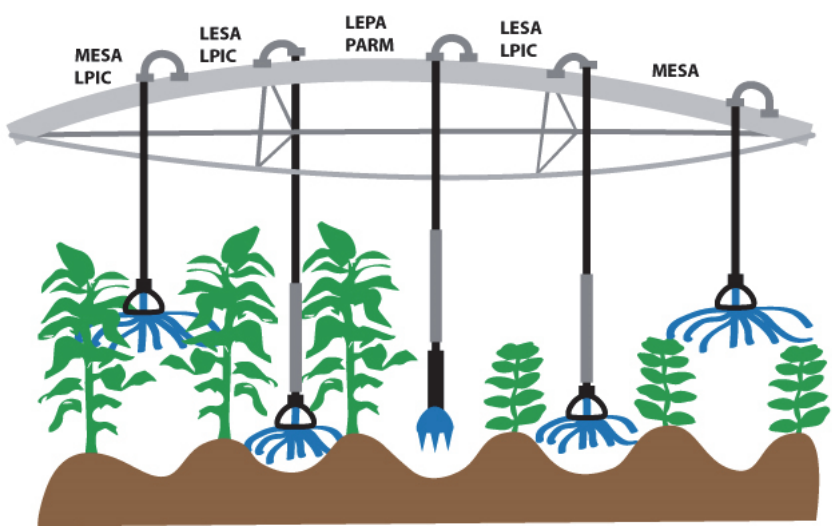

Figure 2. Relative heights of MESA, LESA, LPIC, and LEPA systems in tall and short crops. There can be overlapping definitions (adapted from Howell, 2006).

Table 2. Seven guiding principles of LEPA (after Lyle, 1992).

\begin{tabular}{cl}
\hline No. & \multicolumn{1}{c}{ Guiding Principle } \\
\hline 1 & $\begin{array}{l}\text { Use of a moving overhead tower-supported pipe system (lin- } \\
\text { ear-move or center-pivot travel). }\end{array}$ \\
\hline 2 & $\begin{array}{l}\text { Capable of conveying and discharging water into a single crop } \\
\text { furrow. }\end{array}$ \\
\hline 3 & $\begin{array}{l}\text { Water discharge very near the soil surface to negate evapora- } \\
\text { tion in the air. }\end{array}$ \\
\hline 4 & $\begin{array}{l}\text { Operation with lateral end pressure no greater than } 70 \mathrm{kPa} \\
\text { when the end tower is at the highest field elevation. }\end{array}$ \\
\hline 5 & $\begin{array}{l}\text { Applicator devices are located so that each plant has equal op- } \\
\text { portunity to the water. The only acceptable deviation is where } \\
\text { nonuniformity is caused by nozzle sizing and topographic } \\
\text { changes. }\end{array}$ \\
\hline 6 & Zero runoff from the water application point. \\
\hline 7 & $\begin{array}{l}\text { Rainfall retention that is demonstrably greater than conven- } \\
\text { tionally tilled and managed systems. }\end{array}$ \\
\hline
\end{tabular}

ARS at Bushland, Texas, developed two new terms, MESA and LESA, that can essentially replace LPIC (Howell, 1997). MESA and LESA both emphasize spray application at a relative height above the ground but not necessarily relative to the crop or to the MM lateral. Although the terms do not emphasize pressure in their names, MESA and LESA can both have operating pressure requirements similar to LPIC or LEPA. PARM is an emerging type of in-canopy sprinkler

Table 1. Near-canopy and in-canopy sprinkler systems and their general installation and management guidelines (adapted from Howell, 2006, with PARM added from USDA-NRCS, 2017).

\begin{tabular}{|c|c|c|}
\hline Sprinkler System and Hardware & Tillage and Crop Row Orientation & $\begin{array}{c}\text { Typical Applicator } \\
\text { Height }\end{array}$ \\
\hline $\begin{array}{l}\text { MESA (mid-elevation spray application): } \\
180^{\circ} \text { or } 360^{\circ} \text { spray head; stationary, } \\
\text { rotating, or oscillating plates. }\end{array}$ & $\begin{array}{l}\text { Any tillage system and row orientation. Controlled traffic desired. Basin tillage } \\
\text { with ridge-till or reservoir tillage desirable, with or without beds. Compatible } \\
\text { with no-till, ridge-till, or conservation tillage. }\end{array}$ & $\begin{array}{l}1.2 \text { to } 2.5 \mathrm{~m} \text {, } \\
\text { above crop canopy } \\
\text { for most of season }\end{array}$ \\
\hline $\begin{array}{l}\text { LESA (low-elevation spray application): } \\
180^{\circ} \text { or } 360^{\circ} \text { spray head; stationary, } \\
\text { rotating, or oscillating plates. }\end{array}$ & $\begin{array}{l}\text { Any tillage system with circular crop rows desired for CP systems. Controlled } \\
\text { traffic desired. Basin tillage with ridge-till or reservoir tillage desirable, with } \\
\text { or without beds. Compatible with no-till, ridge-till, or conservation tillage. }\end{array}$ & $\begin{array}{l}0.3 \text { to } 0.6 \mathrm{~m} \text {, } \\
\text { within crop canopy } \\
\text { for most of season }\end{array}$ \\
\hline $\begin{array}{l}\text { LPIC (low-pressure in-canopy): } \\
180^{\circ} \text { or } 360^{\circ} \text { spray head; stationary, } \\
\text { rotating or oscillating plates. }\end{array}$ & $\begin{array}{l}\text { Any tillage system and row orientation. Controlled traffic desired. Basin tillage } \\
\text { with ridge-till or reservoir tillage desirable, with or without beds. Compatible } \\
\text { with no-till, ridge-till, or conservation tillage. }\end{array}$ & 0.3 to $0.6 \mathrm{~m}$ \\
\hline $\begin{array}{l}\text { LEPA (low-energy precision application): } \\
\text { bubbler nozzle. }\end{array}$ & $\begin{array}{l}\text { Circular rows required with CP systems. Controlled traffic desired. Basin tillage } \\
\text { with ridge-till or reservoir tillage required, with beds on non-level landscapes. } \\
\text { Adjustment of irrigation interval is allowable to prevent runoff. }\end{array}$ & $\begin{array}{l}0.3 \text { to } 0.6 \mathrm{~m} \text {, } \\
\text { within crop canopy } \\
\text { for most of season }\end{array}$ \\
\hline $\begin{array}{l}\text { LEPA with drag sock: } \\
\text { any nozzle within drag sock. }\end{array}$ & $\begin{array}{l}\text { Circular rows required with CP systems. Controlled traffic desired. Basin tillage } \\
\text { with ridge-till or reservoir tillage required, with beds (basin tillage is more effec- } \\
\text { tive) on non-level landscapes. Adjustment of irrigation interval is allowable to } \\
\text { prevent runoff. }\end{array}$ & $\begin{array}{l}0 \mathrm{~m} \\
\text { within crop canopy } \\
\text { for entire season }\end{array}$ \\
\hline $\begin{array}{l}\text { PARM (precision application, residue man- } \\
\text { aged): bubbler nozzle or large droplet } \\
\text { dome pattern using a shroud or shield. }\end{array}$ & $\begin{array}{l}\text { Circular rows should be used with CP systems. A no-till or strip-till system with } \\
\text { "flat planting" with at least } 75 \% \text { irrigated high-residue crops. Runoff of applied } \\
\text { irrigation is not allowed. Nozzles in every interrow are recommended. }\end{array}$ & $\begin{array}{l}\leq 0.5 \mathrm{~m} \text {, } \\
\text { within crop canopy } \\
\text { for most of season }\end{array}$ \\
\hline
\end{tabular}


application described by the USDA-NRCS (2017), and there has been little, if any, research published on it. PARM requires $75 \%$ irrigated crop residue to control excessive translocation of applied water and recommends sprinklers between every pair of rows. This latter recommendation runs counter to the earlier recommendation of alternate-row spacing for LEPA (Lyle and Bordovsky, 1983; Bordovsky et al., 1984, 1992; Bordovsky and Lyle 1996).

LEPA is often used in the Texas High Plains with lowcapacity wells and on relatively level fields, whereas LPIC, LESA, and MESA are predominately used in Kansas and the Colorado High Plains. The worldwide annual benefit of LEPA has been estimated to be $\$ 1.1$ billion, with a $\$ 0.477$ billion benefit to consumers in the U.S. (Lacewell, 1998).

The other types of in-canopy and near-canopy sprinkler irrigation do not necessarily require adherence to all seven of the LEPA principles listed in table 2. However, it is unfortunate that there has been a lack of knowledge or a lack of understanding of the importance of these principles, because many of the problems associated with in-canopy and near-canopy sprinkler irrigation can be traced back to a failure to follow or effectively work around one or more of these principles.

\section{EFFECTS OF SPRINKLER SYSTEMS ON WATER LOSSES}

There are numerous water loss pathways for $\mathrm{CP}$ sprinklers, and each sprinkler system has advantages and disadvantages, as outlined by Schneider (2000) and Howell (2006), that must be balanced against the risk of water loss (table 3).

\section{EVAPORATIVE LOSSES}

In-canopy and near-canopy application systems can reduce evaporative losses (tables 3 and 4), but these water savings must be balanced against runoff, deep percolation, and other soil water nonuniformity problems that can occur when the systems are improperly designed and managed. Net sprinkler evaporative losses from solid set sprinklers in Spain ranged from $14 \%$ to $18 \%$ of the applied water during the day, but during the night sprinkler evaporative losses were lower, at approximately $10 \%$, and were a function of wind speed (Martinez-Cob et al., 2008). The researchers concluded that a reduction in ET and transpiration during daytime irrigation moderately increased the resulting sprinkler application efficiency. Similar results were reported from simulation modeling by Thompson et al. (1997), who reported that evaporative losses were reduced to a range of $2 \%$ to $6 \%$ of the total irrigation depth, primarily because transpiration and water evaporation from the soil surface would have occurred even without irrigation. Sprinkler height can also affect water losses, as reported by Ortiz et al. (2009). In their study, a $1 \mathrm{~m}$ sprinkler height, when compared to $2.5 \mathrm{~m}$ sprinkler height, reduced evaporation and drift losses by as much as 33\% and $45 \%$ for daytime and nighttime periods, respectively. They also reported that fixed-plate spray sprinklers had $18 \%$ greater evaporative losses than rotating-plate spray sprinklers, which they attributed to the smaller drop sizes for the fixed-plate sprinklers.

\section{SURFACE WATER REDISTRIBUTION AND RUNOFF WATER LOSSES}

Although evaporative losses are typically reduced with in-canopy and near-canopy sprinkler application, other serious water problems, such as surface water redistribution and runoff, can be exacerbated due to the reduction in the wetted radius of sprinklers operating in or near the canopy.

Some amount of surface water redistribution can be tolerated, particularly if variations in soil infiltration rates and soil water redistribution smooth out the applied water (Hart, 1972; Stern and Bresler 1983; Li and Kawano, 1996; Li, 1998). Simulation modeling by Hart (1972) indicated that differences in irrigation water distribution occurring over an

Table 3. Typical water loss components associated with various sprinkler systems. These descriptions assume that water losses are not exacerbated by excessively poor management (adapted from Schneider, 2000, and Howell, 2006).

\begin{tabular}{|c|c|c|c|c|}
\hline \multirow[b]{2}{*}{ Water Loss Component } & \multicolumn{4}{|c|}{ Sprinkler System } \\
\hline & Overhead $^{[\mathrm{a}]}$ & MESA & LESA & LEPA \\
\hline Droplet evaporation & Yes & Yes & Yes & No \\
\hline Droplet drift & Yes & Yes & No & No \\
\hline Canopy evaporation & Yes & Yes & Yes (not major) & No (chemigation mode only) \\
\hline Impounded water evaporation & No & Yes & Yes & Yes (major) \\
\hline Wetted soil evaporation & Yes & Yes & Yes & Yes (limited) \\
\hline Surface water redistribution & No (but possible) & Yes (not major) & Yes & $\begin{array}{c}\text { Yes (not major unless } \\
\text { surface storage is not used) }\end{array}$ \\
\hline Runoff & No (but possible) & Yes & Yes & $\begin{array}{c}\text { Yes (not major unless } \\
\text { surface storage is not used) }\end{array}$ \\
\hline Percolation & $\begin{array}{l}\text { No (if managed } \\
\text { carefully) }\end{array}$ & $\begin{array}{l}\text { No (but possible with } \\
\text { excessive redistribution } \\
\text { of surface water) }\end{array}$ & $\begin{array}{l}\text { No (but possible with } \\
\text { excessive redistribution } \\
\text { of surface water) }\end{array}$ & $\begin{array}{l}\text { No (but possible with } \\
\text { excessive redistribution } \\
\text { of surface water) }\end{array}$ \\
\hline
\end{tabular}

Table 4. Partitioning of sprinkler irrigation evaporation losses with a typical 25 mm application for various sprinkler systems (adapted from Howell et al., 1991, and Schneider and Howell, 1993).

\begin{tabular}{|c|c|c|c|c|c|}
\hline Sprinkler System & $\begin{array}{c}\text { Air Loss } \\
(\%)\end{array}$ & $\begin{array}{c}\text { Canopy Loss } \\
(\%)\end{array}$ & $\begin{array}{c}\text { Ground Loss } \\
(\%)\end{array}$ & $\begin{array}{c}\text { Total Loss } \\
(\%)\end{array}$ & $\begin{array}{c}\text { Application Efficiency }^{[\mathrm{a}]} \\
(\%)\end{array}$ \\
\hline Impact sprinkler ( 4.3 m height) & 3 & 12 & - & 15 & 85 \\
\hline $\operatorname{MESA}(\sim 1.5 \mathrm{~m}$ height $)$ & 1 & 7 & - & 8 & 92 \\
\hline LEPA ( $\sim 0.3 \mathrm{~m}$ height $)$ & - & - & 2 & 2 & 98 \\
\hline
\end{tabular}

a] Ground runoff and deep percolation are considered negligible in these data. 
approximate distance of $1 \mathrm{~m}$ are probably of little overall consequence and will be evened out through soil water redistribution. Summarizing his own field research, with additional work from Stern and Bresler (1983), Li (1998) illustrated that the Christiansen uniformity (CU) of soil water content averaged an acceptable $90 \%$ to $94 \%$, while the CU of sprinkler water application ranged from approximately $67 \%$ to $83 \%$. In another field study, Li and Kawano (1996) reported that soil characteristics (e.g., texture, infiltration rate, water holding capacity), sprinkler application uniformity, total amount of sprinkler-applied water, and initial soil water content were all important variables in the resulting soil water redistribution, with the latter two factors being most important. Some irrigators in the U.S. Central Great Plains contend that their low-capacity systems on nearly level fields restrict runoff to the general area of application. However, nearly every field has small changes in slope as well as field depressions that cause field runoff on medium to heavy textured soils, in-field redistribution, or deep percolation in ponded areas when the irrigation application rate exceeds the soil infiltration rate. In the extreme drought years of 2000 to 2003 that occurred in the U.S. Central Great Plains, even small amounts of surface water movement affected sprinkler-irrigated corn production (fig. 3).

Although surface water redistribution may or may not result in a direct loss in crop production, field runoff (i.e., when water completely leaves the field of application) is a water loss to crop production that also has environmental consequences, including soil erosion and offsite agrochemical losses. Buchleiter (1991) reported that LEPA on 1\% sloping silt loam soils in northeastern Colorado had no runoff, while runoff exceeded $30 \%$ on a $3 \%$ slope. Runoff from LEPA with basin tillage was approximately $22 \%$ of the total applied water and twice as great as MESA (1.5 m applicator height) for grain sorghum production on a clay loam in Texas (Schneider and Howell, 2000). Basin tillage created by periodic diking (Lyle and Dixon, 1977) of crop furrows ( 2 to $4 \mathrm{~m}$ dike spacing), rather than reservoir tillage created by pitting or digging small depressions ( 0.5 to $1 \mathrm{~m}$ spacing), is often more effective for time-averaging of LEPA application rates, and thus preventing runoff (Schneider, 2000). Increasing the irrigation frequency, and thus lowering the irrigation amount per event, is also used to reduce in-canopy and near-canopy sprinkler application runoff and deterioration of furrow dikes. LEPA performed sufficiently well when coupled with reservoir tillage (i.e., furrow diking on furrow pitting) with field slopes less than $1 \%$ to $2 \%$ on silt loam soils in Kansas (Spurgeon et al., 1995). However, in that study, the flat spray mode (i.e., LESA or LPIC) was more effective in maintaining soil water and ultimately corn yields, probably due to the greater wetted radius as compared to LEPA. Decreasing the irrigation application rate is the most effective way to prevent field runoff losses and surface redistribution within the field (fig. 4), and numerous resources are available to help irrigators appropriately address this topic (Scherer et al., 1999, Rogers et al., 2008; Martin et al., 2017). When runoff and surface redistribution occur using in-canopy sprinklers because of a reduced wetting pattern, one easy solution is to raise the sprinkler height, which increases the wetted radius, but of course moves away from the concept of in-canopy and near-canopy sprinkler application. However, raising the sprinklers can be applied strategically only to the portion of the MM lateral where runoff is a problem. Further discussion of how sprinkler application can be affected by the crop canopy is presented later in this article.

\section{EQUAL OPPORTUNITY OF ACCESS TO SPRINKLER APPLICATION}

The previous section emphasized that water loss pathways must be carefully managed and balanced to achieve the greatest level of success with in-canopy and near-canopy sprinkler applications. Perhaps the most useful guideline for successful in-canopy and near-canopy sprinkler application refers back to LEPA principle 5 in table 2 (Lyle, 1992), which can be paraphrased as "provide each plant equal access to applied water." Using this paraphrase as a working principle, five topics need more extensive discussion: (1) partitioning of the applied sprinkler irrigation amount, (2) symmetry of sprinkler application, (3) spatial orientation, (4) seasonal duration of sprinkler pattern distortion, and (5) combinations of poor design, installation, maintenance, and management aspects.

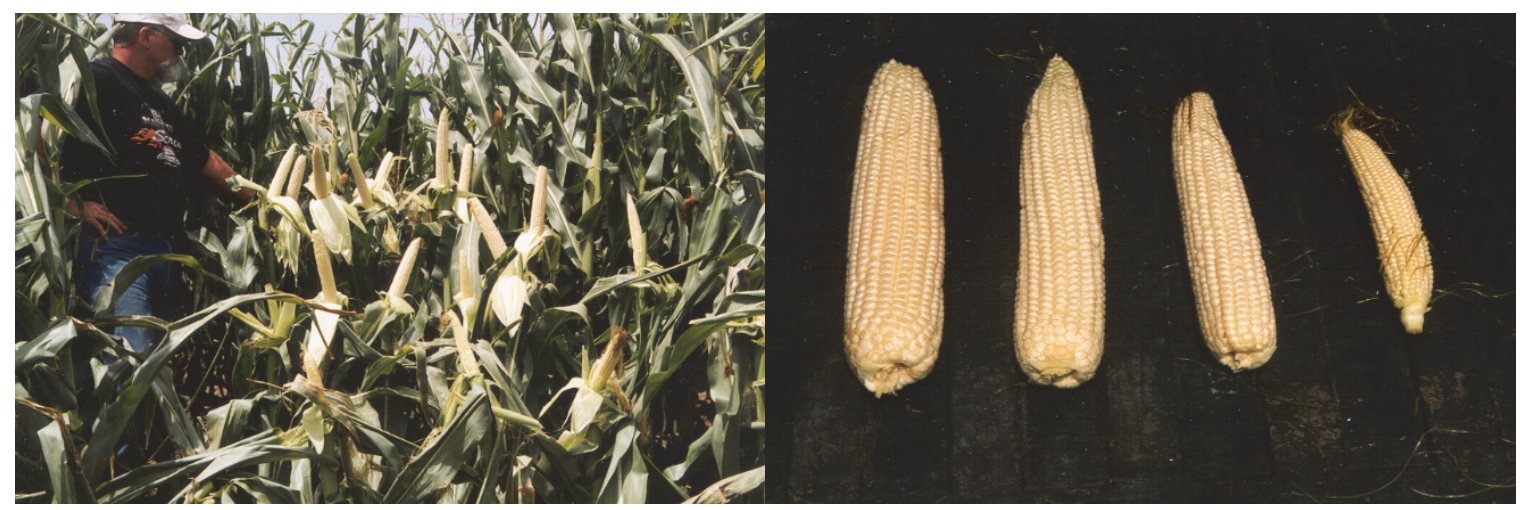

Figure 3. Large differences in corn plant height and ear size for in-canopy sprinkler application over a short distance (10 ft, or four crop rows) as caused by small differences in field microrelief and the resulting surface water movement during an extreme drought year (Colby, Kansas, 2002). The upper stalks and leaves have been removed to emphasize the ear height and size differences. 

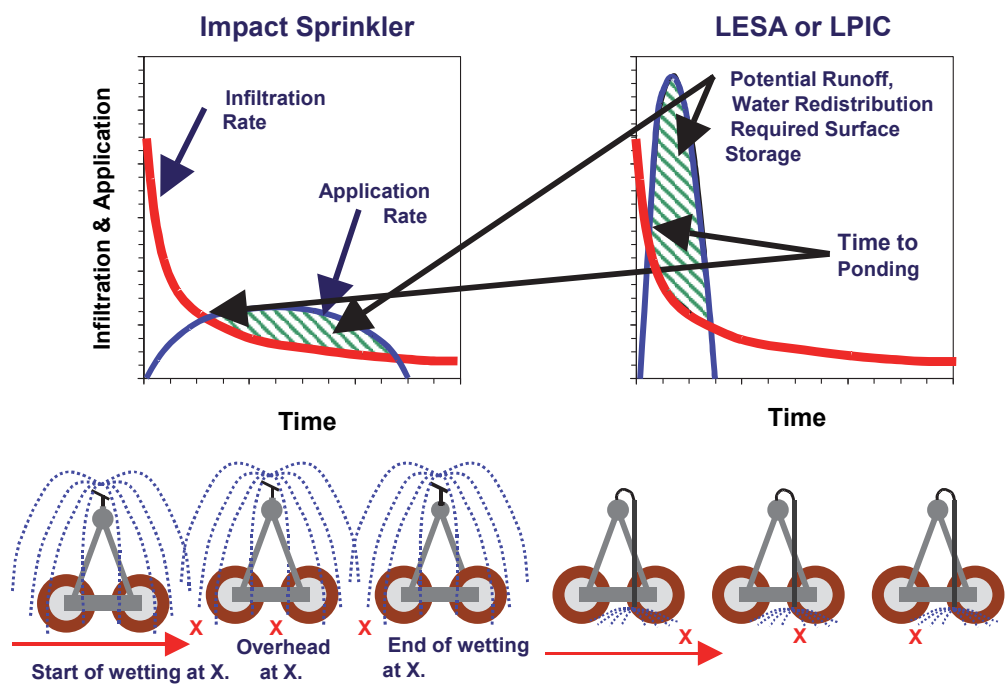

Figure. 4. Runoff and surface water redistribution potential for impact and LESA sprinkler application on an example soil (after Howell, 2006).

\section{PARTITIONING OF APPliEd SPRINKLER IRRIGATION AMOUNT}

The sprinkler application amount that reaches the crop canopy is partitioned into three major components: stemflow, throughfall, and interception storage (Lamm and Manges, 2000). Stemflow is the amount of irrigation water that flows down the leaves to the leaf-stem node and then down the stem to the soil surface. Throughfall represents any irrigation water that reaches the soil surface by falling directly or indirectly through the plant leaf structure. Interception storage is the amount of water temporarily remaining on the plant after irrigation, including both water on the leaf and stem surfaces and water trapped in the leaf-sheath area. Although interception storage is eventually lost as evaporation, crop transpiration is temporarily reduced during the evaporative process (Tolk et al., 1995).

Stemflow is the predominant flow path to the soil after the corn canopy is fully developed, averaging $55 \%$ of the total irrigation amount for corn with a within-row plant spacing of $0.18 \mathrm{~m}$ (fig. 5, using equations from Lamm and Manges, 2000). Throughfall averages approximately $42 \%$ for the same plant spacing, and interception storage (obtained from algebraic closure of the sum of stemflow and throughfall with the total applied water) is approximately $2 \mathrm{~mm}$ for each irrigation event. This interception storage value matches well with previously reported values (Seginer, 1967; Smajstrla et al., 1980; Steiner et al., 1983). When averaged over the entire field, there are very few differences in the partitioning process between above-canopy impact sprinklers and MESA at a height of $2.2 \mathrm{~m}$. However, because of MESA pattern distortion by the crop canopy, there are large partitioning differences between corn rows near and far from the applicator head (fig. 5). The ratio of stemflow to throughfall also increases with increased in-canopy applicator height, effectively allowing the corn plant to serve as a larger funnel.

\section{SYMMETRY OF SPRINKLER APPLICATION}

The importance of uniform water application and/or infiltration has been documented by numerous studies (Zaslav-

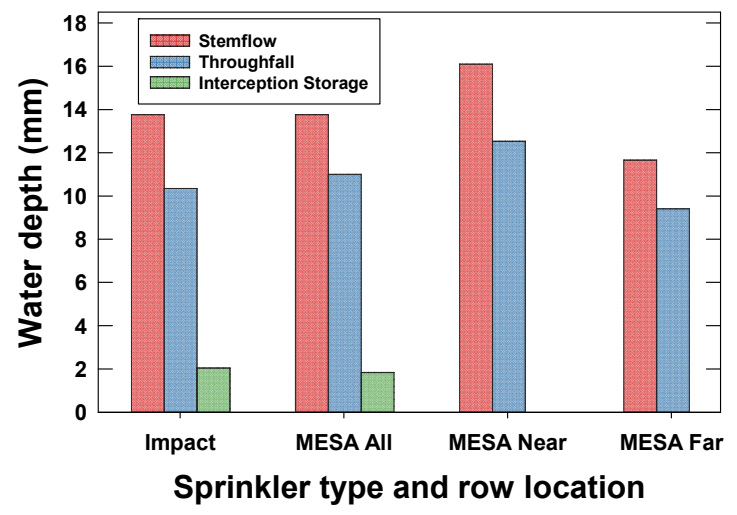

Figure 5. Partitioning of $25 \mathrm{~mm}$ of applied sprinkler irrigation by a fully developed corn canopy (circular rows) as affected by sprinkler type and row location. Impact sprinklers spaced at $12 \mathrm{~m}$ were at $4.1 \mathrm{~m}$ height, and MESA sprinklers spaced at $3 \mathrm{~m}$ were at $2.2 \mathrm{~m}$ height with $0.76 \mathrm{~m}$ row spacing and $0.18 \mathrm{~m}$ plant spacing. MESA pattern distortion resulted in different stemflow and throughfall values for rows that were 0.38 and $1.14 \mathrm{~m}$ away from the nozzle (near and far rows, respectively). Fixed interception storage estimates are provided only for the two sprinkler types and were not evaluated for individual rows with MESA. Calculated values used equations from Lamm and Manges (2000).

sky and Buras, 1967; Seginer 1978, 1979; von Bernuth, 1983; Feinerman et al., 1983; Letey, 1985; Duke et al., 1992; $\mathrm{Li}$ and Kawano, 1996; Li, 1998). Increased uniformity can increase yields and decrease percolation (Seginer, 1979). Improving the uniformity of MM systems is highly desirable for economic and environmental reasons (Duke et al., 1992). Duke et al. (1992) showed that irrigation nonuniformity, such as over-irrigation resulting in nutrient leaching or under-irrigation resulting in water stress, can cause significant economic reductions. An excellent conceptual discussion of the need to consider the extent of crop rooting in irrigation design is presented by Seginer (1979). Although the effective uniformity of in-canopy and near-canopy sprinkler irrigation may be sufficient as experienced by the crop, the actual uniformity of the applied water on the soil surface may be quite low.

In some cases where irrigation is deficient or limited, a lower value of application uniformity can be acceptable (von 


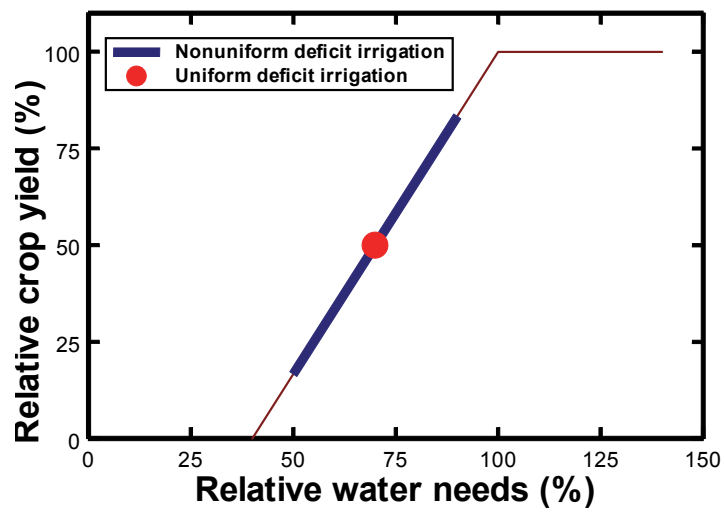

Figure 6. Hypothetical relationship of relative crop yield and relative water needs for nonuniform deficit irrigation (bold range bar) and for uniform deficit irrigation (large dot). The average relative water need is the same for both irrigation schemes, and consequently the average relative yield is also the same (after Lamm, 1998, based on concepts expressed by von Bernuth, 1983).

Bernuth, 1983). For example, when the maximum water application depth falls on the upward sloping line of the yield production function, a crop area that is deficient in water will be compensated for by an area receiving a larger amount of water (fig. 6). The overall production for uniform and nonuniform irrigation is identical because the production function is linear over the range of water applications.

In-canopy and near-canopy sprinkler irrigation does not necessarily result in nonuniform application that is detrimental to crop production. Using a LEPA sprinkler in the furrows between adjacent pairs of crop rows obeys the guiding principle of each plant having equal opportunity to water (fig. 7).

Some irrigators in the U.S. Great Plains are experimenting with wider in-canopy sprinkler spacing (e.g., 2.3, 3.0, 4.6, and even $5.5 \mathrm{~m}$ ) to reduce sprinkler investment costs (Yonts et al., 2005). Spray heads that perform adequately at these intervals above bare ground have a severely distorted pattern when operated within the canopy (fig. 8). This problem is widespread in portions of the U.S. Great Plains. In a transect survey of eight western Kansas counties in 2006 that

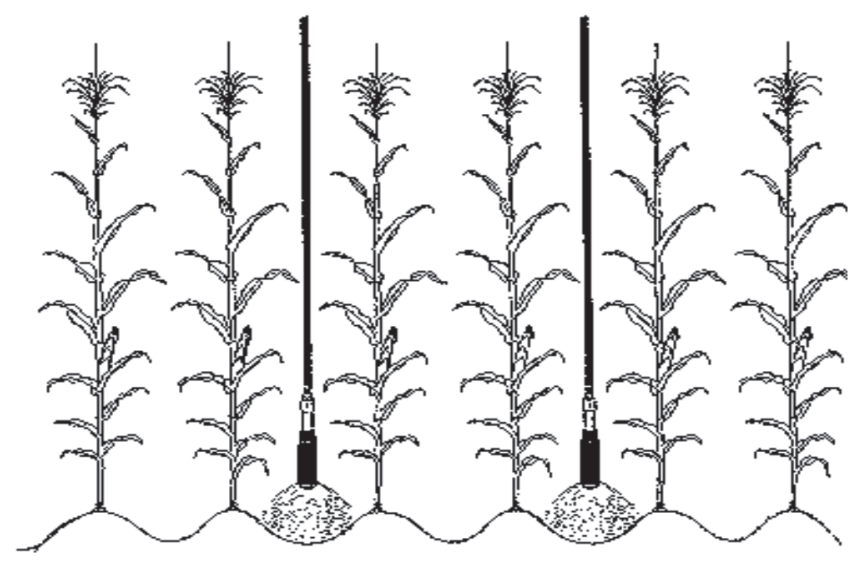

Figure 7. LEPA concept of equal opportunity of plants to applied water. LEPA heads are centered between adjacent pairs of corn rows. A $1.5 \mathrm{~m}$ sprinkler spacing with $0.75 \mathrm{~m}$ circular row spacing results in plants approximately $\mathbf{0 . 3 8} \mathrm{m}$ from the nearest sprinkler (after Lamm, 1998).

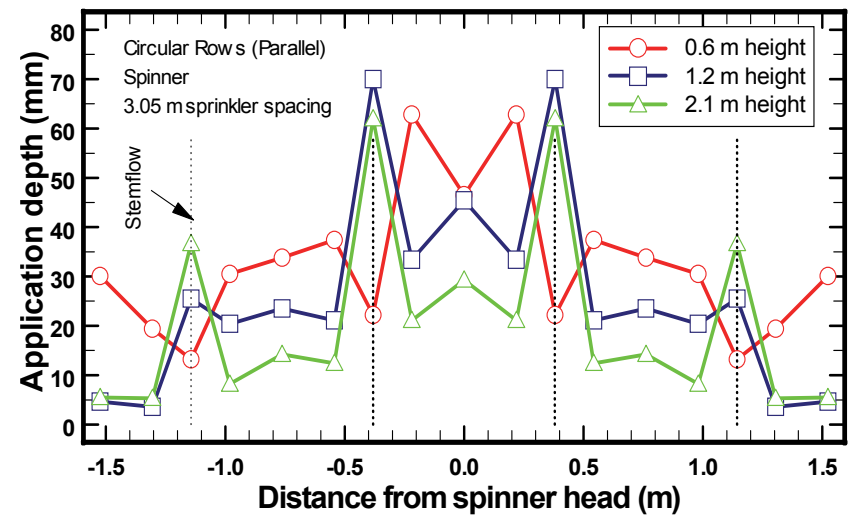

Figure 8. Approximate differences in application depths and patterns for a rotating-plate sprinkler as affected by sprinkler height when the sprinkler spacing is too wide $(3.05 \mathrm{~m})$ for in-canopy application with $0.76 \mathrm{~m}$ spaced corn rows. The $\mathrm{CP}$ lateral traverses parallel to circular rows. Dotted lines indicate locations of corn rows and stemflow values. Areas under curves do not match due to the coarseness of sampling locations and the difficulty of jointly displaying stemflow (point measurement) and throughfall (area measurement). Unpublished data from fully developed corn canopy, July 23-24, 1998, KSU Northwest Research-Extension Center, Colby, Kansas. Data are mirrored about the centerline for illustrative purposes only.

observed $385 \mathrm{CP}$ sprinklers with nozzle height less than $1.2 \mathrm{~m}$, only 131 (or $34 \%$ ) of the systems had nozzle spacings less than $2.4 \mathrm{~m}$ (Rogers et al., 2009).

Although figure 8 shows large application nonuniformity, these differences may or may not always result in yield differences, but they should be considered in irrigation system design. Pattern distortion will result in overirrigation in some areas, which may cause runoff or deep percolation, and under-irrigation in other areas, which may cause crop yield reductions. Sometimes the symmetry problem of excessively wide spacing of sprinklers for incanopy application is not obvious and is only revealed under drought conditions (fig. 9) when water deficits are not obfuscated by precipitation.

\section{SPATIAL ORIENTATION}

When using in-canopy sprinkler application with CP systems, circular planting of the crop rows is recommended so that the crop rows are always perpendicular to the sprinkler lateral. Matching the direction of sprinkler travel to the row orientation satisfies LEPA principles 2 and 5 in table 2 (Lyle, 1992) concerning water delivery to individual crop interrows and each plant's equal access to water. However, producers are often reluctant to plant row crops in circular rows because of the agronomic difficulties. Circular planting can be difficult, resulting in narrow or wide "guess" rows (i.e., rows where adjacent planter passes abut each other). This problem further manifests itself during in-season cultural practices, such as weed cultivation and harvesting. The "guess" row planting problem can be effectively solved with modern planting systems that use global positioning systems (GPS) and for either type of MM system with wheel spacing that matches the planting equipment and crop row geometry. A circular harvesting problem may still exist when the combine harvester and tractor/grain cart must be coordinated over greater distances (i.e., circumference vs. radius). 

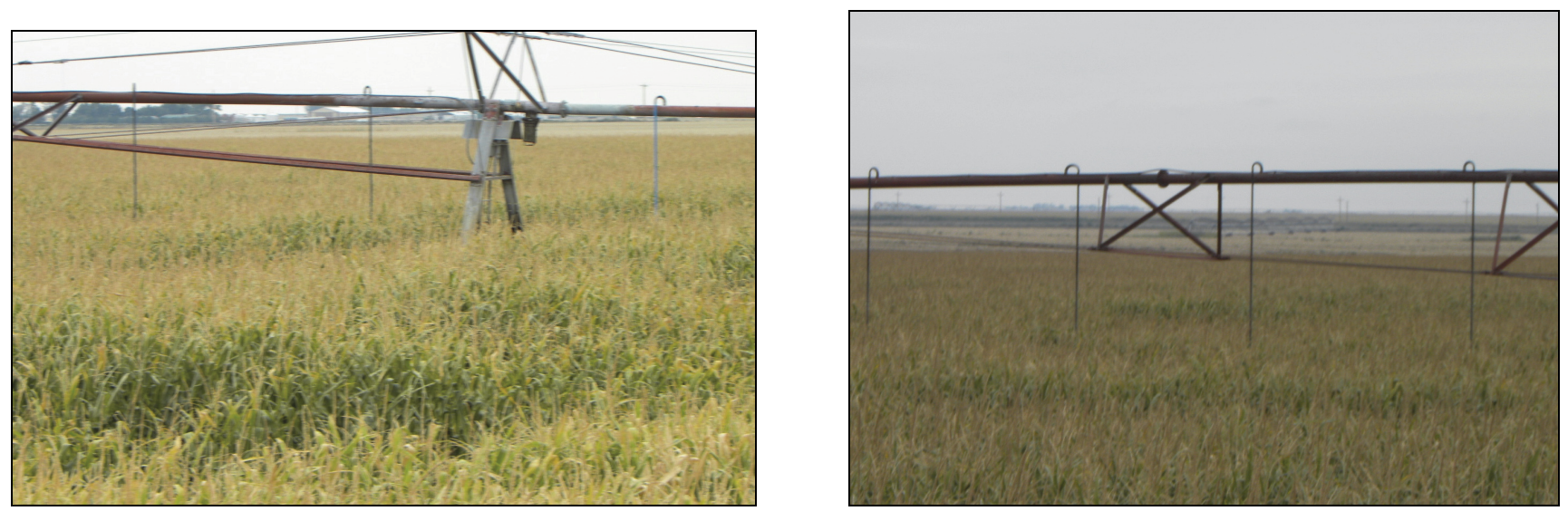

Figure 9. Irregularity of sprinkler-irrigated corn performance in southwest Kansas in 2011 under extreme drought conditions thought to be related to excessively wide nozzle spacing $(3 \mathrm{~m})$ for in-canopy application $(0.6 \mathrm{~m}$ nozzle height).

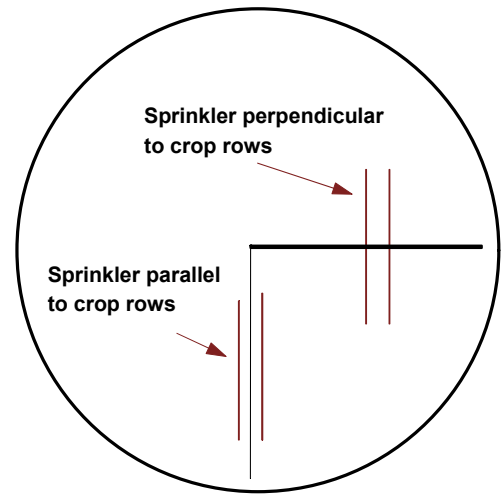

Figure 10. Two problematic orientations for in-canopy sprinklers when crops are not planted in circular rows.

Using in-canopy application for CP sprinkler systems in non-circular crop rows can pose two additional problems (fig. 10). In cases where the CP lateral is perpendicular to the crop rows and the sprinkler spacing exceeds twice the crop row spacing, there will be nonuniform water distribution because of pattern distortion. When the CP lateral is parallel to the crop rows, there may be excessive runoff due to the large amount of water applied in just one or a few crop interrows. There can be great differences in the amount and pattern of in-canopy application between the two crop row orientations (fig. 11). The application differences shown in figure 11 are best considered as point estimates because the coarseness of the sampling locations becomes a critical problem for stemflow and throughfall measurements when the crop row orientation to the $\mathrm{CP}$ lateral changes from parallel to perpendicular. The overall observation from figure 11 is that parallel circular rows impose less distortion of the application pattern than perpendicular straight rows.

\section{SEASONAL DURATION OF SPRINKLER PATTERn Distortion}

Drop spray heads just below the CP lateral truss rods (MESA) at a height of 2.1 to $2.7 \mathrm{~m}$ have frequently been used for over 35 years for corn production in northwest Kansas. This irrigation method has had relatively little negative effect on corn yields, even though the MESA pattern is distorted after corn tasseling, because there is only a small

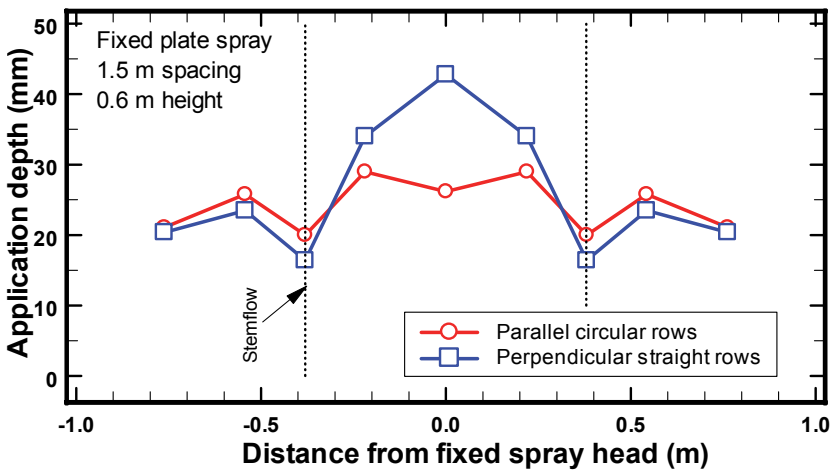

Figure 11. Approximate differences in application amounts and patterns as affected by row orientation to the CP lateral travel direction. Dotted lines indicate stemflow values (point measurements) for both row orientations, although there could have been additional stemflow values for the perpendicular rows. Areas under curves do not match due to the coarseness of sampling locations and the difficulty of jointly displaying stemflow (point measurement) and throughfall (area measurement). Unpublished data from fully developed corn canopy, July 2324, 1998, KSU Northwest Research-Extension Center, Colby, Kansas. Data are mirrored about the centerline for illustrative purposes only.

amount of pattern distortion due to the tassels, and the distortion occurs only during the last 30 to 40 days of growth. In essence, the irrigation season ends before a severe soil water deficit occurs. Compare this situation with LESA at a height of 0.30 to $0.60 \mathrm{~m}$, which may experience pattern distortion for more than 60 days of the irrigation season. Yield reductions might be expected for some corn rows in the latter case because of the extended duration of the pattern distortion. Under dry and elevated evapotranspiration conditions in 1996, row-to-row corn height differences developed rapidly for $3 \mathrm{~m}$ spaced sprinklers at a $1.2 \mathrm{~m}$ sprinkler height following a single $25 \mathrm{~mm}$ irrigation event on a silt loam soil in Kansas (fig. 12). A long-term (1996 to 2001) study at the same location found that lowering an acceptably spaced $(3 \mathrm{~m})$ spinner head from $2.1 \mathrm{~m}$ farther down into the crop canopy (e.g., 1.2 or $0.6 \mathrm{~m}$ ) caused significant row-to-row differences in corn yields (fig. 13).

\section{Combinations of Poor Design, Installation, MaINTENANCE, AND MANAGEMENT ASPECTS}

Sometimes poor design, installation, maintenance, and 


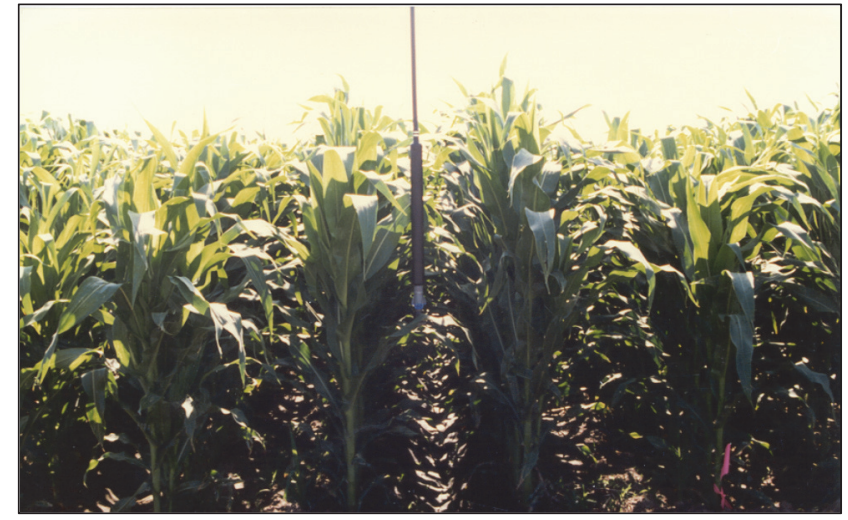

Figure 12. Crop height difference that developed rapidly under a widely spaced $(3 \mathrm{~m})$ in-canopy sprinkler $(1.2 \mathrm{~m}$ height) following a single $25 \mathrm{~mm}$ irrigation event at the KSU Northwest Research-Extension Center, Colby, Kansas. Photo taken on July 6, 1996.

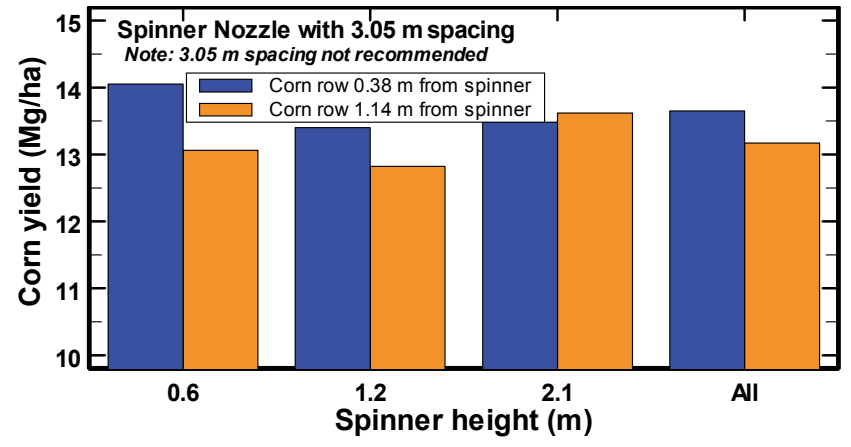

Figure 13. Row-to-row variations in corn yield as affected by sprinkler height for $3 \mathrm{~m}$ spaced in-canopy sprinklers. Sprinkler lateral travel direction was parallel to crop rows. Unpublished data were averaged from four irrigation levels for 1996 to 2001, KSU Northwest ResearchExtension Center, Colby, Kansas.

management problems can exist for years before they are observed in irregular corn performance under sprinkler irrigation. Severe drought conditions may be necessary for some of these subtle effects to combine throughout the season to such an extent that noticeable crop irregularity and yield loss occur. In addition, smaller row-to-row differences in crop yield cannot be measured with the yield monitors on commercial-sized harvesters. An example of combining several of these subtle effects was observed during the severe drought of 2002 in northwest Kansas (fig. 14). The sprinkler height difference allowed at least three effects to combine and reduce corn performance:

- The height difference resulted in unequal flow rates for these low-pressure sprinklers with no pressure regulators.

- With one sprinkler within the canopy while the other two sprinklers were above the canopy, there was incorrect overlap of the sprinkler patterns due to the height difference.

- Evaporative losses would be greater for the sprinklers above the crop canopy.

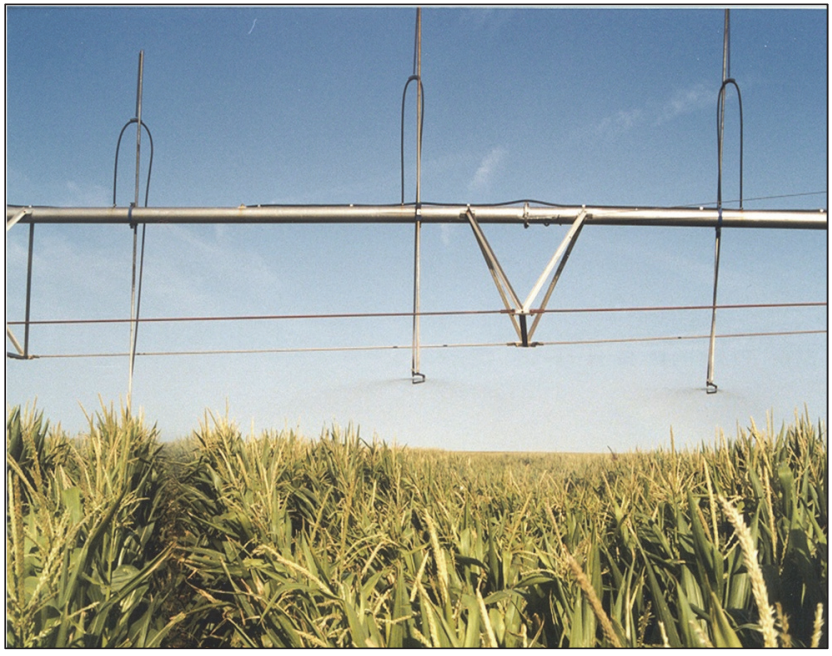

Figure 14. Irregular performance of in-canopy and near-canopy sprinkler-irrigated corn near Colby, Kansas, during extreme drought year of 2002. Nozzle on the left is within the canopy and not visible.

\section{CONCLUDing STATEMENTS}

Short-term and long-term water supply problems in the U.S. have forced those involved with irrigation to look for cost-effective water-saving techniques. Sprinkler irrigation is now the predominant irrigation method in the U.S., particularly in the Great Plains, because of both water and labor savings. Ensuring equal opportunity of crop plants to the applied water has long been recognized as an important tenet of irrigation, yet there continues to be a lack of appropriate attention to this rule, particularly with the newer in-canopy and near-canopy sprinkler application techniques. Important aspects of ensuring equal opportunity include symmetry of the sprinkler application, the spatial orientation of the sprinkler with respect to the crop rows, and the temporal aspects of any pattern distortion by the crop canopy. Engineers, scientists, water agency staff, industry personnel, and irrigators all have important roles in solving this problem. Neglecting the equal opportunity of crop plants to applied irrigation water can easily waste more water and cause more crop yield reductions than the other irrigation problems that irrigators are trying to avoid.

\section{ACKNOWLEDGEMENTS}

Appreciable portions of this article have been presented over the years in proceedings papers at various national and regional conferences, including the American Society of Civil Engineers, the Irrigation Association, and the Central Plains Irrigation Conference. The updated version presented here is a more complete summary intended to be more widely accessible to the scientific community. This article is part of a center-pivot irrigation technology transfer effort supported by the Ogallala Aquifer Program, a consortium of the USDA Agricultural Research Service, Kansas State University, Texas A\&M AgriLife Research, Texas A\&M AgriLife Extension Service, Texas Tech University, and West Texas A\&M University. 


\section{REFERENCES}

Bordovsky, J. P., \& Lyle, W. M. (1996). LEPA irrigation of grain sorghum with varying water supplies. Trans. ASAE, 39(6), 20332038. https://doi.org/10.13031/2013.27706

Bordovsky, J. P., Lyle, W. M., Bender, D. A., Lipe, W. N., Vrubel L., W., \& Lorenz, D. C. (1984). LEPA vs. drip irrigation methods. Ann. Prog. Report, pp. 7-12. College Station: Texas A\&M University Agricultural Experiment Station.

Bordovsky, J. P., Lyle, W. M., Lascano, R. J., \& Upchurch, D. R. (1992). Cotton irrigation management with LEPA systems. Trans. ASAE, 35(3), 879-884.

https://doi.org/10.13031/2013.28673

Buchleiter, G. W. (1991). Irrigation with LEPA. Proc. Central Plains Irrigation Shortcourse (pp. 64-68). Retrieved from https://www.ksre.k-state.edu/irrigate/oow/cpiadocs.html

Duke, H. R., Heermann, D. F., \& Dawson, L. J. (1992). Appropriate depths of application for scheduling center-pivot irrigations. Trans. ASAE, 35(5), 1457-1464. https://doi.org/10.13031/2013.28753

Evans, R. O., Harrison, K. A., Hook, J. E., Privette, C. V., Segars, W. I., Smith, W. B., ... Tyson, A. W. (1998). Irrigation conservation practices appropriate for the southeastern United States. Project Report 32 (D. L. Thomas, Ed.). Atlanta, GA: Georgia Department of Natural Resources.

Feinerman, E., Letey, J., \& Vaux Jr., H. J. (1983). The economics of irrigation with nonuniform infiltration. Water Resour. Res., 19(6), 1410-1414. https://doi.org/10.1029/WR019i006p01410

Foley, J. P., Wigginton, D., \& Eberhard, J. (2006). Optimizing overhead irrigation systems. Proc. Australian Cotton Conf.: Product, Production, Profit - Progressing our National Advantage. Narrabri, NSW, Australia: Cotton Research and Development Corporation (CRDC).

Hart, W. E. (1972). Subsurface distribution of nonuniformly applied surface waters. Trans. ASAE, 15(4), 656-661. https://doi.org/10.13031/2013.37979

Heermann, D. F., \& Kohl, R. A. (1983). Fluid dynamics of sprinkler systems. In Design and operation of farm irrigation systems (pp. 583-618). ASAE Monograph No. 3. St. Joseph, Michigan: ASAE.

Howell, T. A. (1997). What's in a name. Wetting Front, 1(2), 1-3.

Howell, T. A. (2006). Water losses associated with center-pivot nozzle packages. Proc. Central Plains Irrigation Conf. (pp. 1224). Retrieved from https://www.ksre.kstate.edu/irrigate/oow/cpiadocs.html

Howell, T. A., Schneider, A. D., \& Tolk, J. A. (1991). Sprinkler evaporation losses and efficiency. Proc. Central Plains Irrigation Shortcourse (pp. 69-89). Retrieved from https://www.ksre.k-state.edu/irrigate/oow/cpiadocs.html

Lacewell, R. D. (1998). Precision agriculture and value of water. Proc. Great Plains Symp.: Determining the value of water (pp. 46-50). Overland Park, KS: Great Plains Foundation.

Lamm, F. R. (1998). Uniformity of in-canopy center-pivot sprinkler irrigation. ASAE Paper No. 982069. St. Joseph, MI: ASAE.

Lamm, F. R., \& Manges, H. L. (2000). Partitioning of sprinkler irrigation water by a corn canopy. Trans. ASAE, 43(4), 909-918. https://doi.org/10.13031/2013.2987

Lamm, F. R., \& Porter, D. O. (2017). Ogallala aquifer program center-pivot irrigation technology transfer effort. Proc. Irrigation Association Tech. Conf. Fairfax, VA: Irrigation Association.

Letey, J. (1985). Irrigation uniformity as related to optimum crop production: Additional research is needed. Irrig. Sci., 6(4), 253263. https://doi.org/10.1007/BF00262470

Li, J. (1998). Modeling crop yield as affected by uniformity of sprinkler irrigation system. Agric. Water Mgmt., 38(2), 135-146. https://doi.org/10.1016/S0378-3774(98)00055-9
Li, J., \& Kawano, H. (1996). The areal distribution of soil moisture under sprinkler irrigation. Agric. Water Mgmt., 32(1), 29-36. https://doi.org/10.1016/S0378-3774(96)01261-9

Lyle, W. M. (1992). LEPA: Concept and system. Proc. Central Plains Irrigation Short Course (pp. 14-16). Retrieved from https://www.ksre.k-state.edu/irrigate/oow/cpiadocs.html

Lyle, W. M., \& Bordovsky, J. P. (1981). Low-energy precision application (LEPA) irrigation system. Trans. ASAE, 24(5), 12411245. https://doi.org/10.13031/2013.34427

Lyle, W. M., \& Bordovsky, J. P. (1983). LEPA irrigation system evaluation. Trans. ASAE, 26(3), 776-781. https://doi.org/10.13031/2013.34022

Lyle, W. M., \& Dixon, D. R. (1977). Basin tillage for rainfall retention. Trans. ASAE, 20(6), 1013-1017. https://doi.org/10.13031/2013.35693

Martin, D., Kincaid, D. C., \& Lyle, W. M. (2007). Design and operation of sprinkler irrigation systems. In G. J. Hoffman, R. G. Evans, E. Jensen M., D. L. Martin, \& R. L. Elliot (Eds.), Design and operation of farm irrigation systems (pp. 557-631). St. Joseph, MI: ASAE.

Martin, D., Kranz, W., Smith, T., Irmak, S., Burr, C., \& Yoder, R. (2017). Center-pivot irrigation handbook. EC3017. Lincoln, NE: University of Nebraska Cooperative Extension Service.

Martinez-Cob, A., Playan, E., Zapata, N., Cavero, J., Medina, E. T., \& Puig, M. (2008). Contribution of evapotranspiration reduction during sprinkler irrigation to application efficiency. J. Irrig. Drain. Eng., 134(6), 745-756. https://doi.org/10.1061/(ASCE)0733-9437(2008)134:6(745)

McAlavy, T., \& Dillard, P. (2003). LEPA leaps forward: A crop irrigation revolution born on the Texas Plains. Lifescapes (Spring 2003). College Station, TX: Texas A\&M University.

Ortiz, J. N., Tarjuelo, J. M., \& de Juan, J. A. (2009). Characterisation of evaporation and drift losses with center pivots. Agric. Water Mgmt., 96(11), 1541-1546. https://doi.org/10.1016/j.agwat.2009.06.015

Rawlins, S. L., Hoffman, G. J., \& Merrill, S. D. (1974). Traveling trickle system. Proc. 2nd Drip Irrigation Cong. (pp. 184-187). St. Joseph, MI: ASAE.

Rogers, D. H., Alam, M., \& Shaw, L. K. (2008). Sprinkler package effects on runoff. L-903 Rev. Manhattan, KS: Kansas State University Agricultural Experiment Station and Cooperative Extension Service.

Rogers, D. H., Alam, M., \& Shaw, L. K. (2009). Kansas centerpivot survey. MF-2870. Manhattan, KS: Kansas State University Agricultural Experiment Station and Cooperative Extension Service.

Scherer, T. F., Kranz, W., Pfost, D., Werner, H., Wright, J. A., \& Yonts, C. D. (1999). Sprinkler irrigation systems. MWPS 30. Ames, IA: MidWest Plan Service.

Schneider, A. D. (2000). Efficiency and uniformity of the LEPA and spray sprinkler methods: A review. Trans. ASAE, 43(4), 937-944. https://doi.org/10.13031/2013.2990

Schneider, A. D., \& Howell, T. A. (1993). Reducing sprinkler water losses. Proc. Central Plains Irrigation Shortcourse (pp. 43-46). Retrieved from https://www.ksre.kstate.edu/irrigate/oow/cpiadocs.html

Schneider, A. D., \& Howell, T. A. (2000). Surface runoff due to LEPA and spray irrigation of a slowly permeable soil. Trans. ASAE, 43(5), 1089-1095. https://doi.org/10.13031/2013.3001

Seginer, I. (1967). Net losses in sprinkler irrigation. Agric. Meteorol., 4(4), 281-291. https://doi.org/10.1016/00021571(67)90028-3

Seginer, I. (1978). A note on the economic significance of uniform water application. Irrig. Sci., 1(1), 19-25. https://doi.org/10.1007/BF00269004

Seginer, I. (1979). Irrigation uniformity related to horizontal extent 
of root zone. Irrig. Sci., 1(2), 89-96.

https://doi.org/10.1007/BF00263092

Smajstrla, A. G., \& Hanson, R. S. (1980). Evaporation effects on sprinkler irrigation efficiencies. Proc. Soil Crop Sci. Soc., 39, 28-33.

Spurgeon, W. E., Feyerherm, A. A., \& Manges, H. L. (1995). Incanopy application mode and soil surface modification for corn. Appl. Eng. Agric., 11(4), 517-522. https://doi.org/10.13031/2013.25771

Steiner, J. L., Kanemasu, E. T., \& Clark, R. N. (1983). Spray losses and partitioning of water under a center-pivot sprinkler system. Trans. ASAE, 26(4), 1128-1134. https://doi.org/10.13031/2013.34090

Stern, J., \& Bresler, E. (1983). Nonuniform sprinkler irrigation and crop yield. Irrig. Sci., 4(1), 17-29. https://doi.org/10.1007/BF00285554

Thompson, A. L., Martin, D. L., Norman, J. M., Tolk, J. A., Howell, T. A., Gilley, J. R., \& Schneider, A. D. (1997). Testing of a water loss distribution model for moving sprinkler systems. Trans. ASAE, 40(1), 81-88. https://doi.org/10.13031/2013.21251
Tolk, J. A., Howell, T. A., Steiner, J. L., Krieg, D. R., \& Schneider, A. D. (1995). Role of transpiration suppression by evaporation of intercepted water in improving irrigation efficiency. Irrig. Sci., 16(2), 89-95. https://doi.org/10.1007/BF00189165

USDA-NRCS. (2017). Installation of a new center-pivot or linearmove system with a precision application residue managed (PARM) sprinkler. USDA-NRCS Conservation Practice General Specifications (Texas) GS442-1. Washington, DC: USDA Natural Resources Conservation Service.

von Bernuth, R. D. (1983). Uniformity design criteria under limited water. Trans. ASAE, 26(5), 1418-1421. https://doi.org/10.13031/2013.34143

Yonts, C. D., Lamm, F. R., Kranz, W., Payero, J., \& Martin, D. (2005). Impact of wide drop spacing and sprinkler height for corn production. Proc. Central Plains Irrigation Conf. (pp. 99106). Retrieved from https://www.ksre.kstate.edu/irrigate/oow/cpiadocs.html

Zaslavsky, D., \& Buras, N. (1967). Crop yield response to nonuniform application of irrigation water. Trans. ASAE, 10(2), 196-198. https://doi.org/10.13031/2013.39632 